\title{
KEHAMILAN EKTOPIK
}

\author{
Kadek Resa Widiasari ${ }^{1}$, Ni Made Sri Dewi Lestari ${ }^{2}$ \\ ${ }^{1}$ Prodi Kedokteran, Universitas Pendidikan Ganesha \\ ${ }^{2}$ Prodi Kedokteran, Universitas Pendidikan Ganesha \\ e-mail: resa.widiasari@undiksha.ac.id,sri.dewi@undiksha.ac.id
}

\begin{abstract}
Abstrak
Kehamilan ektopik merupakan suatu kehamilan yang terjadi di luar endometrium kavum uteri. Tujuan pembuatan artikel ini untuk mengetahui definisi, faktor risiko, tanda dan gejala, cara mendiagnosis, dan tatalaksana dari kehamilan ektopik sehingga dapat menghindari komplikasi yang mungkin terjadi. Berbagai faktor risiko kehamilan ektopik yaitu pernah mengalami kehamilan ektopik sebelumnya, operasi panggul sebelumnya, penggunaan alat kontrasepsi, riwayat penyakit radang panggul, dan merokok pada saat pembuahan. Kehamilan ektopik ini dapat diklasifikasikan berdasarkan tempatnya menempel dan paling sering terjadi di tuba fallopi khususnya bagian ampula dan diikuti oleh isthmus. Biasanya penderita tidak mengalami gejala yang khas, mirip seperti ibu hamil muda normal, tetapi terdapat trias gejala klinis kehamilan ektopik yaitu amenorea, nyeri abdomen, dan perdarahan pervaginam. Untuk mendiagnosis kehamilan ektopik diperlukan anamnesis, pemeriksaan fisik, dan pemeriksaan penunjang yang tepat. Tatalaksana yang dapat diberikan yaitu terapi medis dengan methotrexate, terapi expectant, dan terapi pembedahan yang terdiri atas laparoskopi, laparotomi, salpingotomi, dan salpingektomi yang dilakukan sesuai dengan indikasinya masingmasing dan yang paling sering dilakukan adalah laparotomi. Kehamilan ektopik tidak dapat dicegah tetapi komplikasi serius dapat dihindari dengan diagnosis dan perawatan dini serta faktor risikonya dapat dikurangi.
\end{abstract}

Kata kunci: kehamilah ektopik, laparotomi, terapi expectant, methotrexate

\begin{abstract}
Ectopic pregnancy is a pregnancy that occurs outside the endometrium of the uterine cavity. The purpose of this article is to find out the definition, risk factors, signs and symptoms, how to diagnose and treat an ectopic pregnancy so as to avoid complications that may occur. Various risk factors for ectopic pregnancy include a previous ectopic pregnancy, previous pelvic surgery, use of contraceptives, a history of pelvic inflammatory disease, and smoking at conception. These ectopic pregnancies can be classified based on their attachment and most commonly occur in the fallopian tube, especially the ampulla. Usually patients don't experience typical symptoms, similar to normal young pregnant women, but there are trias of clinical symptoms of ectopic pregnancy, namely amenorrhoea, abdominal pain, and vaginal bleeding. To diagnose an ectopic pregnancy, a proper history, physical examination and investigations are required. Management that can be given is medical therapy with methotrexate, therapy expectant, and surgical therapy consisting of laparoscopy, laparotomy, salpingotomy, and salpingectomy which are carried out according to their respective indications and the most frequently performed is laparotomy. Ectopic pregnancy cannot be prevented but serious complications can be avoided with early diagnosis and treatment and the risk factors can be reduced.
\end{abstract}

Key words: ectopic pregnancy, laparotomy, therapy expectant, methotrexate 


\section{Pendahuluan}

Kehamilan ektopik berasal dari bahasa Yunani yaitu dari kata 'ektopos', yang memiliki arti tidak pada tempatnya (Soliman dan Salem, 2014). Secara sederhana, kehamilan ektopik dapat diartikan sebagai suatu kehamilan yang terjadi di luar rongga uterus (Varma et al., 2019). Di negara maju, angka kejadian kehamilan ektopik yaitu $1 \%$ sampai $2 \%$ dari semua kehamilan. Insiden diperkirakan lebih tinggi terjadi di negara berkembang, tetapi untuk berapa jumlah spesifik tidak diketahui (Sivalingam et al., 2012). Pertengahan abad ke-20, di Amerika Serikat diperkirakan $0,4 \%$ dari semua kehamilan adalah kehamilan ektopik dan data terbaru menunjukkan angka saat ini lebih tinggi dari 1,4\%. Diperkirakan di Jerman terdapat 20 kehamilan ekstrauterin untuk setiap 1.000 kelahiran. (Taran et al., 2015)

Meningkatnya frekuensi kehamilan ektopik disebabkan oleh sejumlah faktor, diantaranya riwayat kerusakan tuba, baik karena sebelumnya pernah mengalami kehamilan ektopik maupun pembedahan tuba. Riwayat infeksi tuba, penyakit menular seksual, dan meningkatnya usia ibu juga merupakan faktor risiko umum. Satu kali serangan salpingitis (radang pada tuba fallopi) dapat diikuti oleh kehamilan ektopik pada 9\% wanita (Abdulkareem dan Eidan, 2017). Berdasarkan penelitian yang dilakukan oleh Santoso Budi, angka kejadian dari kehamilan ektopik adalah $4,73 \%$, paling banyak pada graviditas kedua yaitu $34,34 \%$, dan pada pasien yang belum mempunyai anak sebanyak 39,39\%. Beberapa faktor risiko yang dapat mempengaruhi, yaitu riwayat operasi sebanyak $10,34 \%$, pasien yang memakai KB sebanyak $20,69 \%$, pasien yang memiliki riwayat abortus sebanyak $41,38 \%$, pasien yang memiliki riwayat operasi dan abortus sebanyak $6,90 \%$, dan pasien dengan KB yang memiliki riwayat abortus sebanyak 20,69\% (Santoso, 2011). Berdasarkan penelitian yang dilakukan dibagian rekam medik RSUP. Prof. Dr. R. D. Kandou Manado, dapat diambil kesimpulan bahwa selama dua tahun mulai dari tanggal 01 Januari 2010 sampai dengan 31 Desember 2011 terdapat sebanyak 41 kasus dari kehamilan ektopik (Logor, Wagey dan Loho, 2013). Komplikasi paling umum dari kehamilan ektopik adalah ruptur, yang terjadi pada 15\%-20\% kehamilan ektopik. Hal tersebut dapat mengancam jiwa jika terjadi perdarahan dan seringkali membutuhkan pembedahan segera (Lee et al., 2018). Berdasarkan hal tersebut, kehamilan ektopik ini penting dibahas dan dipahami agar masyarakat lebih waspada terhadap kehamilannya.

\section{Pembahasan}

Kehamilan ektopik merupakan hasil dari implantasi dan pematangan konseptus di luar rongga endometrium, yang akhirnya berakhir dengan kematian janin. Jika tidak didiagnosis dini dan mendapat perawatan yang tepat waktu, maka kehamilan ektopik dapat mengancam nyawa. (Abdulkareem dan Eidan, 2017). Kehamilan ektopik ini dapat terjadi apabila terjadi ketidaknormalan dalam fisiologi reproduksi manusia yang memungkinkan janin menempel atau tertanam dan matang di luar endometrium yang akhirnya dapat menimbulkan kematian pada janin (Soliman dan Salem, 2014).

Faktor risiko utama kehamilan ektopik berbeda di berbagai negara karena karakteristik budaya dan sosial yang berbeda. Penentuan faktor risiko utama kehamilan ektopik mengarah pada diagnosis cepat dan peningkatan strategi untuk pencegahannya. Berbagai faktor risiko untuk kehamilan ektopik telah diidentifikasi, termasuk kehamilan ektopik sebelumnya, operasi panggul sebelumnya, penggunaan alat kontrasepsi (IUD), riwayat penyakit radang panggul (PID), dan merokok pada saat pembuahan. Wanita yang sudah pernah mengalami kehamilan ektopik akan mempengaruhi kesuburannya dan itu meningkatkan risiko untuk mengalami kehamilan ektopik lagi. Ketika kehamilan ektopik tumbuh dalam tuba fallopii, itu dapat merusak jaringan tuba sekitarnya. Ini memungkinkan telur akan terjebak di sana di kehamilan selanjutnya. Tetapi deteksi dan perawatan dini dapat meminimalkan efek negatif dari kehamilan ektopik. Selain itu, juga akan dipengaruhi oleh kombinasi faktor risiko lainnya.

Operasi panggul sebelumnya dapat 
meningkatkan risiko kehamilan ektopik, dikarenakan hal itu dapat menyebabkan perlengketan. Adhesi akan terbentuk pada wanita setelah menjalani operasi panggul ginekologis. Studi menunjukkan bahwa adhesi terbentuk pada 55-100\% pasien yang menjalani operasi panggul, baik terbuka atau laparoskopi. Meningkatnya jumlah kehamilan ektopik di antara pengguna IUD diyakini terkait dengan beberapa faktor. IUD dalam rongga rahim dapat mencegah telur masuk ke dalam rahim, IUD hanya bisa mencegah kehamilan intrauterin, bukan kehamilan ektopik, dan bakteri yang dibawa melalui pemasangan IUD dapat menyebabkan infeksi tuba fallopi, sehingga dapat meningkatkan risiko kehamilan ektopik.

Penyakit radang panggul (PID) merupakan infeksi endometrium, tuba fallopi dan/atau struktur yang lainnya yang berdekatan, dan disebabkan oleh kenaikan mikroorganisme dari saluran genital bawah. Pada umumnya wanita mengalami PID setelah terkena infeksi menular seksual (IMS), seperti klamidia, sifilis, atau gonore. Merokok dapat mengubah pergantian sel epitel tuba dan dikaitkan dengan perubahan struktural dan fungsional, yang mempengaruhi kejadian dari kehamilan ektopik. Insiden kehamilan ektopik menunjukkan peningkatan yang stabil dengan peningkatan usia ibu saat pembuahan $1,4 \%$ dari semua kehamilan pada wanita berusia 21 tahun menjadi 6,9\% dari kehamilan pada wanita berusia 44 tahun atau lebih karena kelainan kromosom pada jaringan trofoblastik. (Abdulkareem dan Eidan, 2017)

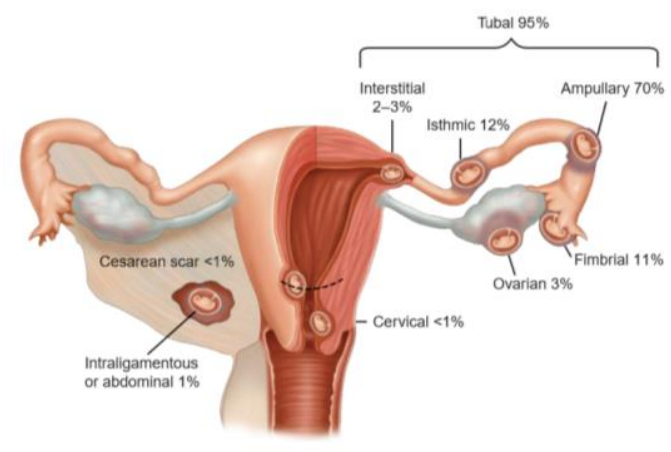

Gambar 1. Lokasi kehamilan ektopik (Sumber: (Cunningham et al., 2014))
Kehamilan ektopik dapat diklasifikasi berdasarkan tempat terjadinya atau tempat menempelnya ovum yang sudah dibuahi di luar uterin. Hampir 95\% kehamilan ektopik ditanamkan di berbagai segmen tuba fallopi dan menimbulkan kehamilan fimbrial, ampula, isthmus, atau interstitial tuba (Gambar 1). Seperti yang tertera pada gambar, ampula adalah tempat yang paling sering, diikuti oleh isthmus. Sisanya $5 \%$ dari implan kehamilan ektopik nontubal di ovarium, rongga peritoneum, serviks, atau bekas luka sesar sebelumnya. Kadangkadang, kehamilan multifetal terdiri dari satu konsepsi dengan implantasi uterus yang berdampingan dengan satu implan ektopik (Cunningham et al., 2014). Berikut ini merupakan klasifikasi kehamilan ektopik menurut (Sari dan Prabowo, 2018), pertama, kehamilan ektopik pada tuba. Kehamilan ektopik pada tuba paling sering terjadi dibandingkan yang lain. Tuba merupakan tempat bertemunya sel telur dan sperma tetapi bukan merupakan tempat yang tepat bagi ovum yang sudah dibuahi untuk menempel dan berkembang, sehingga janin tidak akan tumbuh secara normal atau utuh seperti di dalam uterus. Kehamilan tuba biasanya akan terganggu pada usia kehamilan 6-10 minggu. Berikut merupakan kemungkinan yang akan terjadi pada kehamilan tuba, yaitu ruptur dinding tuba, hasil pembuahan mati dini dan diresorpsi, dan abortus ke dalam lumen tuba.

Kedua, kehamilan pars interstisialis tuba. Pada kehamilan ini, ovum menempel dan berkembang pada pars interstisialis tuba. hal ini jarang terjadi, hanya $1 \%$ dari semua kehamilan tuba. Pada umur kehamilan lebih tua, ruptur pada keadaan ini terjadi dan dapat mencapai akhir bulan keempat. Jumlah perdarahan yang terjadi banyak dan bila tidak dioperasi segera dapat menyebabkan kematian. Operasi yang dapat dilakukan adalah laparatomi yang bertujuan untuk membersihkan isi kavum abdomen dari sisa jaringan konsepsi, darah, dan menutup sumber perdarahan dengan melakukan wegde resection pada kornu uteri tempat tuba pars interstisialis berada.

Ketiga, kehamilan ektopik ganda. Kondisi langka dengan dua kehamilan 
bersamaan yaitu kehamilan intrauterin (IUP) normal dan kehamilan lain atau ektopik. Bentuk yang paling umum adalah kombinasi dari IUP dengan kehamilan ektopik tuba. Frekuensi dari kehamilan yaitu 1:15.000-40.000 kehamilan. Biasanya diagnosis kehamilan ektopiknya dibuat pada waktu penatalaksanan berupa operasi kehamilan ektopik terganggu. Pada laparotomi akan ditemukan uterus membesar sesuai dengan usia kehamilan.

Keempat, kehamilan ektopik ovarial. Kehamilan ektopik ovarial mengacu pada implantasi kantung kehamilan di dalam ovarium dan dapat menyebabkan hingga 3\% kehamilan ektopik. Diagnosis dapat ditegakkan berdasarkan 4 kriteria dari Spiegelberg, yaitu kondisi tuba pada sisi kehamilan harus normal, lokasi kantong janin harus pada ovarium, kantong janin dan uterus dihubungkan oleh ligamentum ovarii proprium, dalam dinding kantong janin jaringan ovarium yang nyata harus ditemukan. (Sotelo, 2019)

Kelima, kehamilan ektopik servikal. Kehamilan ektopik serviks terjadi pada kurang dari $1 \%$ kehamilan ektopik, bila ovum menempel pada kavum servikalis, maka akan terjadi perdarahan tetapi tidak disertai nyeri pada kehamilan awal. Ini didiagnosis ketika kantung kehamilan divisualisasikan dalam stroma serviks, biasanya dalam posisi eksentrik. Biasanya, kehamilan servikal jarang melewati usia 12 minggu dan akan berakhir operatif.

Manifestasi klinis dari kehamilan ektopik yang belum terganggu biasanya tidak khas tergantung dari keadaan umum penderita, penderita jarang mengetahui dan dokter juga sulit dalam mendiagnosis ketidaknormalan dalam kehamilannya tersebut, sampai terjadi abortus atau ruptur pada tuba (Prawirohardjo, 2016). Penderita sering merasakan gejala hamil muda pada umumnya. Pada pemeriksaan dalam, ditemukan pembesaran uterus yang tidak sesuai dengan usia kehamilan dan pada tuba belum teraba kehamilan karena konsistensi tuba yang lunak. Trias dari manifestasi klinis kehamilan ektopik adalah amenorea, nyeri abdomen, dan perdarahan pervaginam.

Lamanya waktu terjadi amenorea berbeda-beda tiap individu mulai dari hitungan hari sampai hitungan bulan. Selain amenorea, terdapat beberapa tanda dan gejala hamil muda yang menyertai, seperti morning sickness, mual, muntah, dan 'ngidam'. Selanjutnya nyeri pada abdomen dapat disebabkan oleh kehamilan ektopik yang ruptur. Jika perdarahannya parah, maka rasa nyeri yang dirasa bisa sampai ke abdomen. Apabila rangsangan darah dalam abdomen mencapai diafragma maka nyeri juga dapat menjalar sampai ke bahu. Apabila darahnya membentuk hematokel atau tertimbun di kavum douglas maka penderita akan merasakan nyeri saat buang air besar (BAB). Perdarahan pervaginam dapat menyebabkan syok karena terjadi gangguan pada sirkulasi umum yang dapat mengakibatkan denyut nadi meningkat (takikardi) dan tekanan darah menurun (hipotensi). Hal ini dikarenakan darah akan tertimbun dalam kavum abdomen dan tidak berfungsi. (Logor, Wagey dan Loho, 2013)

Diagnosis kehamilan ektopik dapat dilakukan melalui 3 tahap pemeriksaan yaitu: anamnesis, pemeriksaan fisik, dan pemeriksaan penunjang. Pertama adalah anamnesis. Gejala yang ditimbulkan tergantung pada usia dari kehamilan ektopik, abortus, atau ruptur pada tuba fallopi, derajat perdarahan yang terjadi, tuanya kehamilan, dan keadaan umum penderita sebelum hamil. Keluhan yang dirasakan oleh pasien adalah nyeri perut bagian bawah yang biasanya muncul tibatiba dan bisa terjadi hanya di satu sisi saja. Perdarahan pervaginam di luar periode menstruasi normal baik ringan maupun berat. Keluhan ini dapat timbul oleh karena darah dari tuba yang ruptur dan terkumpul di bawah diafragma sehingga dapat menyebabkan referred pain pada bahu. Selain itu, keluhan gastrointestinal, seperti diare, tenesmus, dan nyeri saat BAB. (Prawirohardjo, 2016)

Selanjutnya dilakukan pemeriksaan fisik. Jenis dari pemeriksaan fisik yang dapat dilakukan pada pasien kehamilan ektopik sangat beragam dan terkadang tidak begitu membantu. Pasien sering datang dengan penemuan pemeriksaan fisik yang ringan dan massa pada adneksa jarang ditemui. Berikut adalah beberapa pemeriksaan fisik yang dapat ditemukan untuk mendiagnosis adanya kehamilan 
ektopik, yaitu adanya tanda iritasi peritoneal, nyeri tekan abdomen (unilateral/bilateral) atau nyeri tekan pada pelvis yang akan lebih terasa sakit di sisi tempat kehamilan ektopik terjadi, nyeri goyang pada serviks uteri, tanda yang menunjukkan peringatan untuk dilakukan intervensi bedah segera adalah kekakuan abdomen, nyeri tekan abdomen yang hebat, serta tanda-tanda syok hipovolemik, seperti perubahan tekanan darah drastis dan takikardi. Pada pemeriksaan pelvis, uterus dapat menjadi sedikit membesar dan melunak yang biasanya tidak sesuai dengan usia kehamilannya. Massa pada adneksa tempat kehamilan ektopik bernidasi mungkin akan teraba dan kavum douglas yang terisi darah akan menonjol dan nyeri perabaan saat pemeriksaan bimanual. (Sari dan Prabowo, 2018)

Pemeriksaan penunjang penting untuk menegakkan diagnosis kehamilan ektopik. Pemeriksaan penunjang yang dapat dilakukan diantaranya adalah pemeriksaan kadar hormon ( $\beta$-hCG dan progesterone), hemoglobin, leukosit, ultrasonography, kuldosintesis, dan laparoskopi. Kadar $\beta$ hCG berkaitan dengan usia dan ukuran gestasi pertumbuhan embrionik normal. Pada kehamilan ektopik peningkatan kadar $\beta$-hCG tersebut kurang dari kehamilan normal. Kehamilan ektopik umumnya dikaitkan dengan peningkatan hCG tidak lebih dari $66 \%$, atau penurunan tidak lebih dari $13 \%$ dari tingkat dasar, dalam 48 jam. Rasio terletak dalam kisaran ini, bersama dengan nilai hCG absolut di atas $1500 \mathrm{IU} / \mathrm{L}$ tanpa adanya kehamilan intrauterin yang dapat divisualisasikan, dapat diambil sebagai bukti untuk kemungkinan kehamilan ektopik. Kriteria gabungan ini adalah $92 \%$ sensitif dan $84 \%$ spesifik (Taran et al., 2015). Kadar progesteron adalah salah satu cara untuk membedakan kehamilan intrauterin dan ektopik. Pasien dengan kehamilan intrauterin normal memiliki kadar progesteron serum lebih dari $20 \mathrm{ng} / \mathrm{ml}$ (rata-rata $=30,9 \mathrm{ng} / \mathrm{ml}$ ), sementara semua pasien dengan kehamilan ektopik memiliki kadar progesteron kurang dari $15 \mathrm{ng} / \mathrm{ml}$ (rata-rata $=5,7 \mathrm{ng} / \mathrm{ml}$ ). Berbeda dengan kadar $\beta$ hCG, kadar progesteron serum stabil untuk kehamilan 8-10 minggu pertama (Abdulkareem dan Eidan, 2017).

Pemeriksaan kadar hemoglobin $(\mathrm{Hb})$ dan eritrosit juga dapat dilakukan untuk mendiagnosis kehamilan ektopik yang terganggu, terlebih lagi jika ada tanda-tanda perdarahan di dalam rongga perut. Biasanya ditemukan anemia pada kejadian yang tidak mendadak, tetapi harus diperhatikan dan diingat bahwa penurunan $\mathrm{Hb}$ baru akan terlihat setelah 24 jam. Jika dalam perhitungan leukosit secara berturut menunjukkan leukosit meningkat maka menunjukkan adanya perdarahan. Hal ini juga dapat digunakan untuk membedakan kehamilan ektopik dan infeksi pelvis. Pada infeksi pelvis jumlah leukosit umumnya lebih dari 20.000. (Sari dan Prabowo, 2018)

Ultrasonography (USG) adalah salah satu modalitas penting dalam mendiagnosis adanya kehamilan ektopik. Pemeriksaan USG ini lebih tepatnya untuk mengonfirmasi kehamilan intrauterin. Visualisasi kantong kehamilan intrauterin dengan atau tanpa aktivitas jantung janin adalah cara yang adekuat untuk menduga adanya kehamilan ektopik atau tidak. USG dapat dilakukan baik secara transvaginal atupun abdominal. Kuldosintesis merupakan salah satu metode pemeriksaan yang dilakukan untuk mengetahui kondisi dari kavum douglas apakah terdapat darah atau tidak didalamnya. Laparoskopi biasanya menjadi pilihan terakhir yang digunakan sebagai alat bantu diagnostik kehamilan ektopik apabila hasil metode diagnostik yang lain masih meragukan. Kelebihan pemeriksaan ini adalah dapat dinilainya struktur pelvis, ada tidaknya hemo-peritoneum, serta ada tidaknya keberadaan kondisi lain seperti kista ovarium dan endometriosis yang terjadi bersamaan dengan kehamilan intrauterin, dapat menyerupai kehamilan ektopik. Namun, pemeriksaan ini juga memiliki kekurangan yakni hasil positif palsunya juga akan meningkat apabila dilakukan pada kehamilan dengan usia gestasi yang lebih awal. (Prawirohardjo, 2016)

Penatalaksanaan kehamilan ektopik dapat dibagi menjadi pembedahan, terapi medis, dan terapi expectant (menunggu dan waspada) yang dilakukan tergantung pada kondisi pasien. Diagnosis dan tata 
laksana penting diketahui lebih awal mengingat terjadinya kehamilan ektopik yang terganggu dan dapat mengakibatkan komplikasi. Tata laksana mana yang paling tepat tergantung pada penilaian yang sedang berlangsung dan banyak faktor klinis lainnya, itu dirancang untuk masingmasing pasien berdasarkan presentasi dan keparahan kondisi pasien (Sivalingam et al., 2012). Laparoskopi adalah pilihan pembedahan untuk mengonfirmasi dan memfasilitasi pengangkatan dari kehamilan ektopik tanpa laparotomi eksplorasi, namun prosedur terbuka diindikasikan jika pasien secara hemodinamik tidak stabil atau ukuran ektopik menentukan tindakan bedah terbuka. Pasien harus selalu diberi KIE atau konseling tentang risiko konversi menjadi laparotomi saat laparoskopi dilakukan. Biasanya pada manajemen bedah akan melibatkan salpingotomi atau salpingektomi parsial (Juneau dan Bates, 2012). Penatalaksanaan bedah sangat penting dalam kehamilan ektopik yang ruptur. Laparotomi adalah prosedur pembedahan yang paling sering dilakukan. Prosedur laparoskopi dikaitkan dengan waktu operasi yang lebih singkat, kehilangan darah yang lebih sedikit intraoperatif, pemulihan di rumah sakit yang lebih cepat dan persyaratan analgesia yang lebih rendah. Laparotomi harus dilakukan untuk pasien yang mengalami ruptur dan dalam keadaan syok dan kompromi hipovolemik. Jika tabung kontralateral sehat, pilihan yang sering dilakukan adalah salpingektomi, di mana seluruh tuba fallopi atau segmen yang terkena dampak yang mengandung kehamilan ektopik dihilangkan atau diangkat. Salpingotomi adalah prosedur pengangkatan kehamilan ektopik, dengan membedahnya keluar dari tuba, meninggalkan tuba Fallopii in situ dalam upaya untuk menjaga kesuburan di sisi tempat kehamilan ektopik (Sivalingam et al., 2012). Salpingotomi, prosedurnya dimulai dari membuka, mengangkat konseptus, lalu menstabilisasi tuba. Pada bagian atas segmen tuba yang meregang di buat satu insisi linier. Konseptus dari kehamilan ektopik ini dikeluarkan dari lumen tuba. Sisa sisa trofoblas dibersihkan dengan cara melakukan irigasi pada lumen tuba dengan menggunakan cairan ringer laktat yang hangat untuk mencegah kerusakan pada mukosa tuba. (Sari dan Prabowo, 2018)

Terapi medis dengan methotrexate intramuskuler $\left(50 \mathrm{mg} / \mathrm{m}^{2}\right)$ dapat digunakan pada kehamilan ektopik awal $<3,5 \mathrm{~cm}$, tidak rusak, tanpa nada jantung janin, dan tidak ada perdarahan aktif (Juneau dan Bates, 2012). Penatalaksanaan medis adalah pilihan yang dapat diberikan hanya untuk indikasi yang sangat ketat, dan hanya ketika pasien dapat dengan aman diharapkan untuk mematuhi rekomendasi dokter. Data yang memadai tersedia secara eksklusif untuk pengobatan sistemik dengan methotrexate. Obat ini telah terbukti bermanfaat terutama dalam pengobatan jaringan trofoblas persisten dan nilai hCG yang terus meningkat setelah operasi konservatif. Methotrexate, antagonis asam folat, yang aktivitasnya memanifestasikan dirinya terutama dalam sel-sel yang berproliferasi cepat di tempat implantasi, khususnya trofoblas. Tingkat keberhasilan dari pengobatan metotreksat bervariasi dalam literatur, dengan tingkat mulai dari $63 \%$ hingga $97 \%$, ini karena heterogenitas kelompok pasien dan kriteria inklusi, perbedaan protokol dari pengobatan metotreksat, dan berbagai definisi respon pengobatan. Dua protokol yang paling umum adalah protokol dosis tunggal dan protokol multi-dosis. (Taran et al., 2015)

Tatalaksana expectant (menunggu dan waspada). Tatalaksana expectant adalah tatalaksana tanpa intrevensi baik medikamentosa maupun intervensi bedah. Sesuai dengan namanya tatalaksana ini dilakukan dengan cara menunggu kehamilan ektopik berakhir sendiri tanpa terjadinya ruptur. Namun, tidak semua pasien dapat ditatalaksana seperti ini. Pasien yang dapat menjadi kandidat tatalaksana ini adalah pasien yang asimtomatis dan hemodinamik stabil tanpa adanya tanda-tanda ruptur. Selain itu, pasien juga harus memiliki bukti objektif terjadinya resolusi seperti kadar $\beta$-hCG yang menurun. Namun, pada tatalaksana ini perlu ditekankan bahwa pasien harus selalu patuh untuk melakukan followup rutin serta harus mau menerima bahwa risiko ruptur tetap ada. (Sivalingam et al., 2012) 
Secara umum, kehamilan ektopik tidak dapat dicegah, tetapi yang dapat dicegah yaitu komplikasi serius dengan diagnosis dan perawatan dini. Jika memiliki satu atau lebih faktor risiko kehamilan ektopik, pasien dan dokter dapat memonitor di minggu awal kehamilan. Mengurangi risiko tertular infeksi menular seksual (IMS), seperti gonore, sifilis, atau klamidia karena dapat meningkatkan peluang wanita untuk mengalami kehamilan ektopik. Jika seorang wanita mengurangi risikonya tertular salah satu penyakit ini, ia dapat mengurangi risikonya memiliki kehamilan ektopik juga. Terlebih lagi, jika wanita mengalami IMS, penting untuk segera mendapatkan perawatan. Semakin cepat mendapatkan perawatan, semakin kecil kemungkinan akan mengalami peradangan yang dapat merusak sistem reproduksi pasien dan meningkatkan risiko terulangnya kehamilan ektopik. Gejala umum infeksi menular seksual meliputi nyeri perut, nyeri saat buang air kecil (dysuria), keputihan, pendarahan vagina yang abnormal, bau vagina, dan rasa sakit saat berhubungan seksual. Menariknya, transmigrasi sperma intraperitoneal terjadi kira-kira separuh waktu dalam mempengaruhi kehamilan secara spontan. Untuk mengurangi risiko kehamilan ektopik pada wanita dengan tuba fallopii yang rusak secara unilateral, salpingektomi menjadi perawatan bedah yang dipilih, daripada mencoba penyelamatan tuba dan perbaikan. (Abdulkareem dan Eidan, 2017)

\section{Simpulan}

Berdasarkan pemaparan diatas, kehamilan ektopik merupakan kehamilan yang tidak pada tempatnya dan memiliki gejala yang tidak khas karena mirip dengan kehamilan normal sehingga dibutuhkan diagnosis sedini mungkin dengan cara anamnesis, pemeriksaan fisik, dan juga pemeriksaan penunjang untuk mengetahui apakah kehamilannya normal atau abnormal dan dapat dilakukan tindakan atau pemilihan penatalaksanaan yang tepat baik itu pembedahan, medikamentosa, dan terapi expectant sehingga dapat menghindari komplikasi yang akan terjadi jika terlambat ditangani. Kehamilan ektopik tidak dapat dicegah, akan tetapi faktor risiko dapat dikurangi.

\section{Daftar Rujukan}

Abdulkareem, T. A., \& Eidan, S. M. (2017). Ectopic Pregnancy: Diagnosis, Prevention dan Management. Intech, 3, 49-66.

Cunningham, F. G., Leveno, K. J., Bloom, S. L., Spong, C. Y., Dashe, J. S., Hoffman, B. L., Casey, B. M., \& Sheffield, J. S. (2014). Williams Obstetrics (24th ed.). Mc Graw Hill Education.

Juneau, C., \& Bates, G. W. (2012). Reproductive outcomes after medical dan surgical management of ectopic pregnancy. Clinical Obstetrics dan Gynecology, 55(2), 455-460.

Lee, R., Dupuis, C., Chen, B., Smith, A., \& Kim, Y. H. (2018). Diagnosing ectopic pregnancy in the emergency setting. Ultrasonography, 37(1), 78-87.

Logor, S. C. D., Wagey, F. W., \& Loho, M. F. T. (2013). Tinjauan Kasus Kehamilan Ektopik Di Blu Rsup Prof. Dr. R. D. Kdanou Manado Periode 1 Januari 2010 - 31 Desember 2011. Jurnal E-Biomedik, 1(1), 40-44.

Prawirohardjo, Sarwono. (2016). IImu Kebidanan (Ed. 4, Cet. 5). Jakarta : PT Bina Pustaka Sarwono Prawirohardjo. ISBN 978-979-8150-25-8

Santoso, B. (2011). Analisis Faktor Kehamilan Ektopik. Ners, 6, 164.

Sari, R. D. P., \& Prabowo, A. Y. (2018). Buku Ajar: Perdarahan pada Kehamilan Trimester 1. Fakultas Kedokteran Universitas Lampung.

Sivalingam, V. N., Duncan, W. C., Kirk, E., Shephard, L. a, \& Danrew, W. (2012). Diagnosis dan management of ectopic pregnancy. 37(4), 231-240.

Soliman, A. T., \& Salem, H. A. (2014). Undisturbed tubal ectopic pregnancy. Evidence Based Women's Health Journal, 4(4), 179-183.

Sotelo, C. (2019). Ovarian Ectopic Pregnancy: A Clinical Analysis. Journal for Nurse Practitioners, 15(3), 224227.

Taran, F. A., Kagan, K. O., Hubner, M., Hoopmann, M., Wallwiener, D., \& Brucker, S. (2015). Diagnosis dan 
Ganesha Medicina Journal, Vol 1 No 1 Maret 2021

Treatment of Ectopic Pregnancy.

(2019). Magnetic resonance imaging of Deutsches Arzteblatt International, 112, 693-704.

Varma, R., Parikh, B., Beyer, C., Ghosh, S., Du, D., Aaron, G., \& Kamath, A. tubal ectopic pregnancy: correlation with intraoperative findings. Clinical Imaging, 58(May), 194-200. 